\begin{tabular}{l|l} 
Notaice & e-ISSN: 2655-9404 \\
Vol. 2 No. 2, Juni 2019 & DOI: 10.20473/ntr.v2i2.13916 \\
\hline
\end{tabular}

Article history: Submitted 13 May 2019; Accepted 28 May 2019; Available online 1 June 2019.

\title{
Pewarisan Menurut Hukum Waris Islam Terhadap Sistem Kekerabatan Matrilineal Minangkabau
}

\author{
Ira Damayanti Putri, Dhea Amelisca and Sarfia Nengsih \\ radinda.wanda@gmail.com \\ Universitas Airlangga
}

\begin{abstract}
The matrilineal kinship system is a kinship system that follows the maternal bloodline. This kinship system, the child connects himself with mother's relatives, based on women's lineage unilaterally. The position of daughters in a family in the Minangkabau indigenous people is very important in terms of the continuation of the clan from a family, as well as in the case of heirs who receive their inheritance rights, this occurs because the Minangkabau people generally adhere to the Matrilineal family system. But in its development with the entry of Islam in Indonesia, most of the Minangkabau people were influenced by the teachings of Islam, so that in the position of heirs there was a position of heirs that contradicted the Islamic inheritance law with customary inheritance law in the Minangkabau community. This issue is very interesting to discuss in order to find out the influence and change with the coming of the teachings of Islamic inheritance law on the Minangkabau matrilineal inheritance system. After conducting a literature or normative research, it can be seen that the Minangkabau community after the arrival of Islamic teachings carried out two inheritance systems, namely for high inheritance inherited by the Matrilineal collective inheritance system, for low inheritance inherited by using Bilateral individual inheritance systems.
\end{abstract}

Keywords: Law of Inheritance of Islam; Law of Inheritance; Matrilineal; Minangkabau Customs.

\begin{abstract}
Abstrak
Sistem kekerabatan matrilineal adalah system kekerabatan yang mengikuti garis keturunan ibu. System kekerabatan ini, anak menghubungkan dirinya dengan kerabat ibu, berdasarkan garis keturunan perempuan secara unilateral. Kedudukan anak perempuan dalam sebuah keluarga pada masyarakat adat Minangkabau sangatlah penting dalam hal penerusan Marga dari suatu keluarga, demikian juga dalam hal ahli waris yang mendapat hak warisnya, hal ini terjadi dikarenakan masyarakat Minangkabau umumnya menganut sistem kekeluargaan Matrilineal. Namun dalam perkembangannya dengan masuknya agama Islam di Indonesia, sebagaian besar masyarakat Minangkabau dipengaruhi oleh ajaran Agama Islam, sehingga dalam kedudukan ahli waris terdapat kedudukan ahli waris yang bertentangan antara Hukum waris Islam dengan Hukum Waris adat pada masyarakat Minangkabau. Permasalahan ini sangat menarik untuk dibahas agar mengetahui adanya pengaruh serta perubahan dengan datangnya ajaran hukum waris Islam terhadap system kewarisan matrilineal Minangkabau. Setelah dilakukan penelitian dengan metode kepustakaan atau normatif, dapat diketahui bahwa masyarakat Minangkabau pasca datangnnya ajaran Islam, melaksanakan dua sistem kewarisan yaitu untuk harta pusaka tinggi diwariskan dengan sistem kewarisan kolektif Matrilinial, untuk harta pusaka rendah di wariskan dengan menggunakan sistem kewarisan individual Bilateral.
\end{abstract}

Kata Kunci: Hukum Waris Islam; Hukum Waris Adat; Matrilineal; Adat Minangkabau.

\section{Pendahuluan}

Hukum waris adat di Indonesia tidak terlepas dari pengaruh susunan masyarakat

kekerabatan yang berbeda. Hazairin mengaakan bahwa "Hukum waris adat 
mempunyai corak tersendiri dari alam pikiran masyarakat yang tradisional dengan bentuk kekerabatan yang sistem keturunannya patrilineal, matrilineal, parental atau bilateral". ${ }^{1}$ Sudah sejak lama masyarakat Minangkabau menarik perhatian banyak orang, baik dari dalam maupun luar negeri. Hal itu disebabkan karena sistem kekerabatan matrilineal yang dianut oleh masyarakat Minangkabau di tengah sistem patrilineal yang pada umumnya dinaut oleh masyarakat dunia. Kekhasan itu memancing timbulnya keingintahuan. Pada sistem kekerabatan matrilineal atau garis keturunan menurut garis ibu, kaum perempuan menempati posisi yang sangat penting di dalam kehidupan bermasyarakat. Keberadaan suku, kaum, dan paruik di Minangkabau tergantung pada perempuan. Suku atau kaum bisa menjadi punah bila perempuan tidak ada lagi. Kedudukan perempuan yang menjamin keberadaan suku atau kaum menyebabkan perempuan disimbolkan sebagai "Limpapeh rumah nan gadang". Oleh sebab keberadaan perempuan sebagai penjamin keberlangsungan dan keberadaan suatu suku atau kaum menyebabkan perempuan amat menentukan atas harta benda kaum yang dinamakan sebagai "amban puruak aluang bunian" bagi rumah gadang. Kaum perempuan yang akan memelihara harta benda itu dengan sebaik-baiknya sebagai jaminan hidup bagi anak-anak serta kaumnya. ${ }^{2}$

Sistem pembagian hukum adat Minangkabau, berdasarkan pada system keturunan yang ditarik dari garis ibu yaitu sistem pewarisan (matrilineal) dimana kedudukan anak pewarisan. Perempuan adalah keturunan penerusnya, akan tetapi ahli warisnya adalah semua anak, laki-laki dan perempuan yang berasal dari harta ibu. $^{3}$

Sistem kekerabatan matrilineal merupakan system kekerabatan yang mengikuti garis keturunan ibu. System kekerabatan ini, anak menghubungkan dirinya dengan kerabat ibu, berdasarkan garis keturunan perempuan secara

\footnotetext{
1 Oemar Moechthar, Perkembangan Hukum Waris Praktik Penyelesaian Sengketa Kewarisan Di Indonesia (Prenadamedia Group 2019).[195].

2 Kemendikbud, 'Kedudukan Dan Peran Bundo Kanduang' (Kemendikbud, 2014) <http:// repositori.kemdikbud.go.id/10797/1/Kedudukan dan peran bundo kanduang.pdf $>$ accessed 16 July 2019.

3 ibid.
} 
unilateral. Dalam system kekerabatan ini, keturunan menurut garis ibu dipandang sangat penting sehingga menimbulkan hubungan pergaulan kekeluargaan yang jauh lebih rapat dan meresap diantara para warga persektuannya. System kekerabatan matrilineal menerapkan bentuk perkawinan semanda, dilakukan tanpa pembayaran jujur dari pihak pria kepada wanita. Setelah dilakukannya perkawinan, pria harus menetap di pihak kekerabatan isteri. Sistem kekerabatan inilah yang dianut oleh masyarakat Minangkabau. ${ }^{4}$

Sistem kekerabatan di matrilineal pada masyarakat Minangkabau mempunyai tujuh ciri, yaitu: ${ }^{5}$

1. Keturunan yang dihitung menurut garis ibu;

2. Suku yang terbentuk menurut garis ibu;

3. Tiap orang diharuskan menikah dengan orang di luar sukunya (exogami);

4. Kekuasaan yang terdapat dalam suku, secara teori, terdapat di tangan ibu akan tetapi jarang sekali dipergunakannya, sedangkan;

5. Kekuasaan terdapat pada saudara laki-lakinya;

6. Perkawinannya bersifat matrilokal, yaitu suami yang berkunjung ke isterinya; dan

7. Hak-hak dan pusaka diwariskan oleh mamak untuk kemenakannnya, dari saudara laki-laki ibu kepadaaanak saudara perempuan.

Masyarakat Minangkabau ialah masyarakat dengan mayoritas memeluk agama islam. Meskipun mayoritas beragama muslim, tetapi meraka tetap mempertahankan hukum, disamping hukum islam untuk melakukan aktivitas kehidupannya, lebih dikhususkan dalam pembagian harta warisan. Masuknya agama Islam pada masyarakat adat Minangkabau, tahap demi tahap memberi pengaruh yang besar pada adat istiadat Minangkabau. Puncak dari pengaruh masuknya Islam adalah dirubahnya falsafah adat sebanyak 4 (empat) kali yang pada awalnya berfalsafah Alam takambang menjadi guru hingga berubah terakhir kali menjadi Adat besandi syara', syara' besandi kitabullah. Perubahan-perubahan yang terjadi sebanyak 4 (empat) kali tersebut adalah dalam rangka penyesuaian antara adat dengan agama Islam yang masuk hingga menjadi satu satunya agama yang diakui oleh masyarakat Minangkabau hingga saat ini. Perbenturan yang berarti antara adat dengan Islam

\footnotetext{
4 Soepomo, Bab-Bab Tentang Hukum Adat (Pradnya Paramita 2003).[65].

5 Helmy Panuh, Peranan Kerapatan Adat Nagari (Raja Grafindo Persada 2012). [41].
} 
pada awal penyiarannya terdapat dalam bidang sosial, khususnya yang berhubungan dengan sistem kekerabatan yang menentukan bentuk perkawinan dan pergaulan. ${ }^{6}$

Pada saat lembaga hibah mulai berkembang belum adanya pemisahan yang tegas antara harta pusaka tinggi dengan harta pencaharian. Dengan demikian, menghibahkan harta kepada anak berarti membawa harta kaum keluar lingkungan kaum. Setelah harta pusaka itu terpisah dengan harta pencaharian, barulah hibah terhadap harta pencaharian lebih mudah dilaksanakan. Terpisahnya harta pencaharian dari harta pusaka berlaku secara berangsurangsur dan baru sampai pada tahap akhir dengan adanya pengesahan formal dari kesepakatan bersama para ninik mamak, alim ulama dan cerdik pandai dan angkatan muda yang datang sebagai utusan seluruh alam Minangkabau, yang dikenal dengan Kerapatan Orang Empat Jenis yang berlangsung di Bukittinggi tanggal 02-04 Mei 1952.7 Maka ditetapkan dua prinsip pokok dalam penyelesaian harta peninggalan, yaitu:

a. Harta pusaka tinggi yang telah didapati turun temurun dari nenek moyang menurut garis ibu, diturunkan menurut sepanjang adat; dan

b. Harta pencaharian yang menurut adat bernama harta pusaka rendah diturunkan menurut peraturan syara'.

Hasil dari kesepakatan itu merupakan suatu kompromi antara tuntutan pihak agama dan tuntutan pihak adat. ${ }^{8}$ Pihak agama telah melepaskan harta pusaka untuk diwariskan secara adat dan mendapatkan lapangan harta pencaharian untuk diwariskan sesuai dengan tuntutan agama. ${ }^{9}$

Hasil kesepakatan yang dicapai dalam kerapatan tersebut dikuatkan pula dalam Seminar Hukum Adat Minangkabau yang diadakan di Padang pada tanggal 21-25 Juli 1968. Dalam keputusan huruf F dalam seminar ini menetapkan: ${ }^{10}$

6 Sidi Gazalba, Konflik Penyesuaian Antara Adat. Agarna Dan Pengaruh Barat, Makalah disampaikan pada Seminar Islam di Mingkabau, Minang Permai, Padang, 1969.

7 Amir Syarifuddin, Pelaksanaan Hukum Kewarisan Islam Dalam Lingkungan Adat Minangkabau (Gunung Agung 1984).[4].

8 ibid.[289].

9 ibid.

${ }^{10}$ Mochtar Naim Ed, Menggali Hukum Tanah Dan Hukum Waris Minangkabau, Center for Minangkabau (Studies Press 1968).[243]. Kesimpulan Seminar Hukum Adat Minangkabau, dalam seminar ini dihadiri oleh Cendikiawan yang mewakili seluruh lapisan Masyarakat Minangkabau. 
I. 1. Harta Pusaka di Minangkabau merupakan harta badan hukum yang diurus dan diwakili oleh Mamak kepala waris diluar dan didalam pengadilan;

2. Anak kemenakan dan Mamak Kepala Waris yang termasuk kedalam badan hukum itu, masing-masing bukanlah pemilik dari harta badan hukum tersebut.

II. 1. Harta pencaharian diwarisi oleh ahli waris menurut Hukum Faraidh;

2 Yang dimaksud dengan harta pencaharian ialah seperdua dari harta yang diperdapat oleh seseorang selama dalam perkawinannya ditambah dengan harta bawaannya sendiri;

3 Seseorang dibenarkan berwasiat baik kepada kemenakannya maupun kepada yang lain-lainnya hanya sebanyak-banyaknya sampai sepertiga dari harta pencarian.

Persoalan ini menarik untuk diteliti lebih lanjut karena dalam masyarakat Minangkabau, terkait persoalan pembagian harta warisan diharapkan hukum waris islam dan hukum waris adat secara bersamaan. Dalam tulisan ini akan menganalisis penerapan kedua hukum tersebut dalam pembagiannya harta warisan. terdapat tiga rumusan masalah yang akan dibahas dan dijelaskan dalam tulisan ini, yaitu bagaimana dengan konsepsi hukum waris islam, dan bagaimana pula konsepsi hukum waris adat, dan bagaimana kontekstualisasi hukum waris islam dan hukum waris adat dalam suatu masyarakat Minangkabau.

Berdasarkan uraian diatas, dapat dirumuskan pokok permasalahan yang akan di teliti dan dibahas secara lebih mendalam pada penelitian ini sebagai berikut:

1. Pengaruh masuknya hukum waris Islam terhadap sistem kewarisan matrilineal Minangkabau;

2. Faktor-faktor apa saja yang mengakibatkan perubahan dalam pembagian harta warisan pada masyarakat Minangkabau.

Berdasarkan pada masalah yang telag diuraikan sebelumnya, maka tujuan dari penelitian yang dilakukan penulis ialah:

1. Mengetahui pengaruh hukum waris Islam terhadap system kewarisan matrilineal Minangkabau. 
2. Mengetahui faktor-faktor apa saja yang menyebabkan terjadinya perubahan dalam pembagian harta warisan pada masarakat Minangkabau.

\section{Metode Penelitian}

Metode penelitian yang akan diterapkan adalah penelitian kepustakaan yang normatif. Metode penelitian kepustakaan adalahpenelitian yang mengacu pada norma-norma hukum dan putusan pengadilan.Metode penelitian ini dikenal sebagai penelitian doktrinal yang dalam hal ini merujuk baik pada hukum positif di dalam Putusan Makamah Agung, serta pendapat-pendapat para ahli (doktrin).

Metode analisis data yang digunakan pada peneltian ini adalah matode kualitatif, ini didasarkan pada berbagai alasan sebagai berikut: Pertama, anal isis kualitatif didasarkan pada paradigma hubungan yang dinamis antara teori, konsep dan data yang merupakan umpan batik atau modification yang tepat dari teori dan konsep yang didasarkan pada data yang dikumpulkan. Kedua, data yang dianalisis beraneka ragam, masing-masing memiliki sifat dasar yang berbeda antra yang satu dengan yang lainnya, serta tidak mudah untuk di kuantifisir. Ketiga, sifat dasar data yang akan dianalisis dalam penelitian ini adalah bersifat menyeluruh dan merupakan satu kesatuan yang integral. Hal ini menunjukkan adanya keanekaragaman data serta diperlukanya informasi yang mendalam.

Penelitian deskriptif ini merupakan suatu penelitian yang dimaksudkan untuk mendapatkan keterangan mengenai dua sistem kewarisan pada masyarakat ad at Minangkabau dan pelaksanaanya pada kenyataannya dan sistem kewarisan pada masyarakat ad at Minangkabau terse but di masa yang akan datang.

Dalam penelitian ini disajikan data sekunder dimana data tersebut diperoleh dari kepustakaan dengan menganalisis data sekunder hingga mendapat suatu kesimpulan yang utuh dengan hasilnya akan bersifat deskriptif prespektif analitis.

\section{Hasil Penelitian dan Pembahasan}

Dalam Islam waris disebut dengan istilah al-farai-dh yang merpakan kata jamak dari kata al-faridhah. Kata faraidh sendiri berasal dari kata al-fardhu yang 
memiliki makna al-taqdiir yaitu suatu ketentuan.

Asal kata waris sendiri dari bahasa Arab, yaitu berbentuk jama' yang terdapat pada kata mirats, ${ }^{11}$ yang memiliki arti harta peninggalan yang telah ditinggalakan oleh otang yang telah meninggal dan diwariskan kepada ahli warisnya, ${ }^{12}$ dalam al-Quran kata waris sendiri dibahas sebanyak 23 ayat ${ }^{13}$ diantaranya ayat yang dijadikan dasar untuk pembahasan waris adalah: surat an-Nisa (4): 11 yang memiliki arti:

"Allah mensyari'atkan bagimu tentang (pembagian pusaka untuk) anakanakmu.Yaitu: bahagian seorang anak lelaki sama dengan bagahian dua orang anak perempuan; dan jika anak itu semuanya perempuan lebih dari dua, maka bagi mereka dua pertiga dari harta yang ditinggalkan; jika anak perempuan itu seorang saja, maka ia memperoleh separo harta. Dan untuk dua orang ibu-bapa, bagi masing-masingnya seperenam dari harta yang ditinggalkan, jika yang meninggal itu mempunyai anak; jika orang yang meninggal tidak mempunyai anak dan ia diwarisi oleh ibu-bapanya (saja), maka ibunya mendapat sepertiga; jika yang meninggal itu mempunyai beberapa saudara, maka ibunya mendapat seperenam. (Pembagianpembagian tersebut di atas) sesudah dipenuhi wasiat yang ia buat atau (dan) sesudah dibayar hutangnya. (Tentang) orang tuamu dan anak-anakmu, kamu tidak mengetahui siapa di antara mereka yang lebih dekat (banyak) manfaatnya bagimu.Ini adalah ketetapan dari Allah.Sesungguhnya Allah Maha Mengetahui lagi Maha Bijaksana”.

Pada tahun 1285-1522, agama Islam Mahzab Syafei sudah mulai dan berkembang di Minangkabau Timur setelah daerah itu tahluk dibawah kekeuasaan kerajaan Samudra Pasai.Akan tetapi pengislaman besar-besaran dan terencana terjadi setelah kota-kota di pesisir Minangkabau berada dibawah pengaruh Aceh. ${ }^{14}$ Penerimaan hukum Islam menjadi sumber dasar bagi adat, berdasarkan pula atas kesadaran masyarakat Islam Minangkabau bahwa sifat dari hukum Islam itu adalah suatu keharusan (compulsory), yang berarti bahwa hukum Islam itu wajib dilaksanakan oleh seluruh umat muslim. Bagi umat muslim tidak diberikan pilihan untuk menggunakan hukum Islam atau tidak mempergunakan hukum Islam, hanya ada satu pilihan yaitu wajib melaksanakan hukum Islam.

\footnotetext{
${ }^{11}$ Suparman Usman dan Yusuf Somawinata, Fiqh Mawaris (Gaya Media Pratama 1997).[13].

12 ibid.[14].

13 Muhammad Fu'ad Abdul Baqy, Al Mu'jam Al Mufahros Lil Al Fadhil Al Qur'an (Diponegoro 1945).[25].

${ }^{14}$ Amir Syarifuddin (n 7).Op.Cit.[120].
} 
Persoalan pembagian waris ketika pewaris masih hidup, seringkali dimunculkan oleh pemilik harta atau calon pewaris maupun calon ahli waris. Padahal secara syariat, tidak ada pembagian harta pada warisan apabila pemilik harta itu masih hidup. Karena salah satu persyaratan dalam pembagian waris adalah adanya kematian dari pewaris dengan kata lain syarat menjadi pewaris adalh seseorang yang telah meninggal dunia dan meninggalkan harta. Jika calon ahli warisnya masih hidup, maka tidak ada kepentingan dengan pembagian harta waris. Oleh karena itu, hanya bisa melakukan hibah atau wasiat, tetapi bukan pembagian waris. ${ }^{15}$

Berbeda dengan cara pembagian waris pada masayarakat adat Minangkabau yang berorientasi pada sistem kekerabatan Matrilineal, pada hukum waris Islam bagian waris anak perempuan di namakan dengan ahli waris dzawil furudz dimana ahli waris yang porsi bagiannya telah ditentukan dalam Al-Qur'an dan Sunnah, besar porsi bagian anak perempuan dalam QS. an-Nisaa (4) ayat 11 juga menentukan besar porsi bagian yang berhak diterima oleh ahli waris anak perempuan yang terdiri dari tiga macam tergantung dari situasi dan kondisi tertentu, yakni:

a. Bagian untuk anak perempuan adalah $1 / 2$ harta warisan jika hanya ada seseorang dan tidak memiliki anak laki-laki yang menariknya menjadi asabhah.

b. Bagian anak perempuan adalah $2 / 3$ bagian harta warisan apabila terdapat dua orang atau lebih anak peremuan dan tidak ada yang menariknya menjadi ashabah.

c. Anak perempuan dapat menjadi ashabah karena adanya anak laki-laki dengan syarat bagian seseorang anak laki-laki sama dengan dua bagian seorang anak perempuan.

d. Anak perempuan menutup ahli waris paman (saudara pewaris), hal ini didasarkan pada: ${ }^{16}$

i. Putusan Pengadilan Agama Mataraam No. 85/pdt.G/1922, 5 November 1992

ii. Putusan Mahkamah Agung No. 86/AG/1994, 27 Juli 1995

iii.Putusan Pengadilan Agama Pekalongan No.820/G/1991, 27 Januri 1992

iv. Putusan Pengadilan Tinggi Agama Semarang No. 69/G/1992, 29 Desember 1994

v. Putusan Mahkamah Agung No. 184 K/AG/1995, 30 September 1996

Begitupun dengan cucu perempuan dan saudara perempuan, porsi bagian warisnya akan lebih sedikit jika ahli waris dzawil furudz ini menjadi ashabah.

15 Sri Hajati, dkk., Buku Ajar Hukum Waris: Adat, Islam dan Burgerlijk Wetboek (Airlangga University Press 2018).[116].

16 ibid.[69]. 
Dalam sistem kekerabatan matrilineal atau dikenal dengan garis keturunan ibu atau garis keturunan perempuan. System matrilineal, yaitu sistem kekeluargaan yang menarik garis keturunan pihak nenek moyang perempuan. Yang melanjutkan keturunan adalah perempuan, akan tetapi ahli waris adalah semua anak laki-laki dan perempuan yang berasal dari harta ibu. Kewajiban alimentasi bapak sebagai kepala keluarga tidak ada, karena kewajiban alimentasi menjadi beban ibu, ibu memperoleh atau dapat hidup dari harta saudara laki-lakinya. Bentuk perkawinan dalam sistem kekerabatan matrilineal yaitu sistem perkawinan di mana perkawinan diatur menurut tata tartib garis ibu, sehingga setelah dilangsungkan pernikahan seorang istri tetap tinggal dalam clan-nya yang matrilineal. ${ }^{17}$

Soerojo Wignjodipoerno berpendapat, hukum adat waris meliputi normanorma hukum yang menetapkan harta kekayaan baik yang materil maupun yang immateriil dari seseorang yang dapat diserahkan kepada keturunannya serta yang sekaligus juga mengatur saar, cara dan prosses peralihannya. ${ }^{18}$

Sedangkan Ter Haar berpendapat bahwa, hukum waris adat ialah aturanaturan hukum yang mengatur tentang bagaimana cara dari masa ke masa proses penerusan dan peralihan harta kekayaan yang berwujud dan tidak berwuzud dari generasi ke geneerasi. ${ }^{19}$

Soepomo mengemukakan, hukum waris adat adalah peraturan yang memuat pengaturan mengenai proses penerusan serta engoperan barang-barang harta benda dan barang-barang yang tidak termasuk harta benda (immateriele goederen) dari suatu angkatan manusia kepada turunannya. ${ }^{20}$

Dalam masyarakat Matrilineal, harta dibedakan menjadi 2 (dua): $:^{21}$ pbarang-baranghrang yang tidak termasukhaederen)dari suatu aepa masyarabedakan menjadi 2 (dua):22

\footnotetext{
${ }^{17}$ Oemar Moechthar (n 1).Op.Cit.[196-197].

${ }^{18}$ H. Zainuddin Ali, Pelaksanaan Hukum Waris Di Indonesia (Sinar Grafika 2010).[1].

${ }^{19}$ H. Hilman Hadikusuma, Pengantar Hukum Waris Di Indonesia (Mandar Maju 2003).[211].

${ }^{20}$ Soejono Soekanto, Hukum Adat Indonesia (Rajagrafindo Persada 2012).[259].

${ }^{21}$ Sri Hajati dkk (n 16).[16].
} 


\section{Harta Pusaka Tinggi}

Selalu didapat/diperoleh dari warisan, dan diwaris oleh ahli waris secara kolektif.

\section{Harta Pusaka Rendah}

Adalah semua harta pencarian yang diperoleh dalam perkawinan dan diperoleh sebelum kawin juga. Dapat diwaris secara indivbidual oleh ahli waris.

Amir Syarifuddin berpendapat di dalam bukunya; Pelaksanaan Hukum Kewarisan Islam Di Lingkungan Adat Minangkabau, menyatakan bahwa karena kesepakatan itu diambil oleh utusan yang mewakili seluruh lapisan masyarakat adat Minangkabau maka keputusan itu dapat di tempatkan sebagai adat yang diadatkan yang menduduki kedudukan tinggi dalam tingkatan adat Minangkabau, akan tetapi karena sifat dari adat yang diadatkan tersebut adalah berlaku untuk satu nagari dan tidak dapat dipaksakan terhadap nagari lain ${ }^{23}$ maka penulis merasa lebih tepat untuk mengatakan bahwa keputusan dari orang empat jinih tersebut sebagai peraturan adat sebana adat (adat sebenarnya adat) yang menduduki tempat tertinggi dalam tingkatan adat, karena keputusan tersebut berlaku untuk seluruh masyarakat Minangkabau dan merupakan realisasi dari diterimanya falsafah ada! besandi syara', syara' besandi kitabullah yang berada dalam tingkatan adat sabana adat.

Pada saat ini banyak masyarakat Minangkabau yang merantau, dengan tujuan untuk memperbaiki kehidupan di daerah asalnya. Dan telah ketergantungan dengan mata pencarian mereka tersebut. Dengan hasil pencarian tersebut mereka membesarkan anak-anaknya dari hasil kerja keras selama ini. Sehingga menyebabkan anak-anak mereka jauh dari sosok mamaknya, induak bako, dengan tanpa sengaja mereka telah hidup pada susunan keluarga baru, didalam susunan keluarga yang berdiri sendiri. Sebagian besar anak-anak ini umumnya tidak mengetahui tentang adatnya sendiri, sehingga jika mereka telah berumah tangga maka akan membentuk keluarga baru yang berdiri sendiri, sebagai mana mereka dibesarkan di lingkungan mereka.

\footnotetext{
23 ibid.[76-77].
} 
Masyarakat Minangkabau yang berada di perantauan mengalami pembaruan kebudayaan dengan masyarakat sekitar dimana terdapat budaya yang berbeda-beda satu sama lainnya. Pepatah minang mengatkan "dimana bumi di pijak disitu langit di junjung”. Karena adanya pencampuran kebudayaan tersebut maka masuklah kebiasaan kebudayaan lain pada perantauan. Sama halnya dengan hal kewarisan, dimana kedudukan seorang anak lebih diutamakan dari kemenakan-kemenakan, karena anak dianggap sebagai penerus generasinya kelak.

Pada masyarakat Minangkabau dalam proses pewarisan tidak langsung dibagi harta warisan tersebut. Hal ini dianggap tidak sopan oleh masyarakat Minangkabau seolah-oleh berharap agar pewaris segera meninggal dunia agar harta tersebut dapat dibagi-bagi. Ini telah menjadi kebiasaan di dalam masyarakat Minangkabau sendiri agar harta warisan tersebut tidak langsung dibagi.

Seorang perempuan di Minangkabau memiliki kedudukan yang istimewa sehingga dijuluki dengan Bundo Kanduang, memainkan peranan dalam menentukan keberhasilan pelaksanaan keputusan-keputusan yang dibuat oleh kaum lelaki dalam posisi mereka sebagai mamak (paman atau saudara dari pihak ibu), dan penghulu (kepala suku). Pengaruh yang besar tersebut menjadikan perempuan Minang disimbolkan sebagai Limpapeh Rumah nan Gadang (pilar utama rumah). Walau kekuasaan sangat dipengruhi oleh penguasaan terhadap azet ekonomi namun kaum lalaki dari keluarga pihak perempuan tersebut masih tetap memegangootoritas atau memiliki legitimasi kekuasaan pada komunitasnya.

Masyarakat Minangkabau tetap mempertahankan sistem matrilineal hingga saat ini, walaupun hanya sebatas diajarkan secra turun temurun dan tidak terdapat sanksi adat apabila ada yang tidak menjalankan sistem kekerabtan tersebut. Setiap orang Minangkabau misalnya, cendrung untuk menyerahkan harta pusaka dimana seharusnya dibagikan kepada anak menurut hukum faraidh sebagai mana yang terdapat dalam islam hanya untuk anak perempuannya. Dan ia akan memberikan itu kepada anak perempuannya juga dimana ini akan berlangsung seterusnya. Sehingga Tsuyoshi Kato dalam disertasinya menyebutkan bahwa sistem matrilineal akan semakin kuat di dalam diri masyarakat Minangkabauuwalau 
mereka telah tinggal di kota-kota di luar Minang sekalipun dan memulai mengenal sistem patrilineal. ${ }^{24}$

Namun jika masyarakat Minangkabau yang di perantauan tidak lagi mempertahankan sistem kewarisan tersebut yang ditarik dari garis keturunan ibu. Tetapi mereka menerapkan sistem kewarisan yang berlaku di daerah tempat tinggal mereka masing-masing, maka masyarakat minang yang merantau tidak lagi mempertahankan hukum adatnya sendiri, melainkan menggunakan hukum waris konvensional. Walaupun masih ada tendensi dalam penerapan hokum adat minag. Rata-rata sitem pewarisan di Indonesia adalah sistem bagi rata, tidak terdapat perbedan pembagian anatar laki-laki dan perempuan. Sehingga dapat disimpulkan bahwa masyarakat Minangkabau pada hakekatnya apabila di perantauan sebagian akan tetap mempertahankan hokum waris adat matrinial, sebagian lagi ada yang menyesuaikan dengan hukum waris konvensional.

Dalam musyawarah di Bukittinggi tahun 1952 dan Seminar Hukum Adat Minangkabau di Padang tahun 1968 memberikan hasil bahwa " terhadap Harta Pencaharian berlaku Hukum Faraidh, sedangkan terhadap Harta Pusaka berlaku Hukum Adat". Hasil dari musyawarah yang menjadikan dasar pada masyarakat Minangkabau untuk membagi harta hasil pencarian mereka berdasarkan hukum Islam. Sama halnya dengan masyarakat Minangkabau di daerah yang diteliti, mayoritas telah menjawab bahwa harta warisan di bagi berdasarkan hukum Islam sesuai dengan kepercayaan yang dianut. Responden mengatakan bahwa harus mengikuti ajaran Allah SWT dan mengerti bahwa harta pusaka tinggi di bagi berdasarkan ketentuan hukum adat dan harta pencarian di bagi berdasarkan ketentuan hukum Islam.

Apabila seseorang telah merantau, maka mereka akan berusaha sendiri, tidak lagi untuk kemenakan-kemenakan akan tetapi hanya teruntuk kelurga inti mereka. Yang hanya terdiri suami/isteri dan anak kandung saja, dan membesarkan ketrunan meraka di daerah tersebut. Dan keturunan tersebut nantinya juga akan mencari

${ }_{24}$ Tsuyoshi Kato, Adat Minangkabau Dan Merantau Dalam Perspektif Sejarah (PT Balai Pustaka 2005).[45]. 
nafkah untuk keluarga inti mereka. Dikarenakan mereka telah terbiasa dengan dibesarkan oleh keluarga inti saja, maka pada saat mereka dewasa nantinya akan mengikuti kebiasaan tersebut, ini akan berdampak pada pada harta pusaka, sehingga mereka akan mengembangkan usaha bukan dari harta pusakanya. Oleh sebab itu pada zaman sekarang hasil dari kerja keras mereka hanya teruntuk keluarga inti saja. Dimana peran kepala keluarga akan berdampak penting disini.

Akibat adanya factor dari pendidikan, mayarakat perantauan Minangkabau akan dipimpin oleh kepala keluarga (suami/ayah). Peran kepala keluarga disini ia akan bertanggung jawab atas keluarga mereka sendiri, dan berusaha untuk menafkahi keluarganya dari hasil kerja kerasnya sendiri. Hal ini yang salah satu pengaruh pendidikan dimana ia akan berfikirin rasional.

Alasan pendidikan juga mempengaruhi masyarakat untuk ikut merantau, di karenakan mereka ingin berfikir terbuka dan mempelajari budaya lain dan akan berusaha untuk meraih kesuksesan, demi meperbaiki kehidupan keluarga mereka. Dengan suksenya mereka diperantauan, maka perlaha ia akan membawa orang tuanya di kampung untuk menetap ditempat tersebut.

Pendidikan tidak hanya memberikan dampak positif disini, akan tetapi juga memberikan sedikit dampak negative yaitu dengan perkembangan pendidikan, maka paraperantau tersebut akan terfokus hanya pendidikan akademiknya saja, dengan begitu perlahan ajaran adat akan terlupakan sedikit demi sedikit. Walaupun mereka berpendidikan tinggi akan tetapi hanya sedikit orang di perantauan yang mengerti akan adat istiadat mereka, terlebih lagi yang lahir di perantauan, mereka akan buta terhadapa adat istiadat mereka sendiri.

\section{Kesimpulan}

Dalam hal ini penulis akan mencoba menarik beberapa kesimpulan dari sebelumnya. Disamping itu penulis juga akan mencoba untuk memberikan saran dan masukan yang berhubungan dengan pokok masalah. Adapun kesimpulan penulis adalah:

1. Bahwa pengaruh masuknya Agama Islam pada kewarisan adat Minangkabau 
adalah terjadinya perkembangan dalam hukum kewarisan adatnya. Perubahan pada falsafah adat menjadi falsafah yang mendasarkan adat pada agama Islam yaitu; adat basandi syara', syara' basandi kitabullah mendorong berbagai perubahan dalam hukum adat Minangkabau termasuk pada proses dalam perkawinan di masyarakat adat yang meningalkan pola ekstended family menjadi nuclear family. Oleh karena corak perkawinan mempengaruhi bentuk pewarisan adat, maka perubahan yang terjadi pada perkawinan mempengaruhi waris adat Minangkabau terse but. Diterimanya keputusan atas pertemuan pada tanggal 2-4 Mei 1952 di Bukittinggi, yang dihadiri orang Empat Jinih, keputusan mana membagi harta menjadi dua yaitu harta pusako tinggi di turunkan secara adat dan harta pusako rendah diturunkan secara syara', menguatkan status kewarisan Islam dalam hukum waris adat Minangkabau. Dengan demikian maka masyarakat Minang pasca mengenal ajaran Islam, menerapkan dua sistems pewarisan yaitu untuk harta pusaka tinggi diwariskan dengan sistem kewarisan kolektif Matrilinial, untuk harta pusaka rendah di wariskan dengan sistem kewarisan individual Bilateral. Dengan ini, dapat dipastikan bahwa hukum adat dan agama Islam di Minangkabau tidaklah bertentangan. Tetapi sebaliknya, agama Islam menyempurnakan adat Minangkabau.

2. Yang menyebabkan perubahan yang terjadi pada harta pewarisan ialah pengaruh ajaran agama islam, pendidikann,ekonomi, dan lingkungan. Dengan mengikuti ajaran agama makan sedikit demisedikit ajaran adat akan di kesampingkan. Factor lainnya yang juga mempengaruhi adalah factor ekonomi, karena banyaknya kebutuhan ekonomi maka menyebabkan terjadinya perubahan yang ada. Sedangkan factor pendidikan disini akan berpengaruh pada hak dan kewajiban. Untuk factor lingkungan pada daerah perantau menyebabkan secra perlahan hukum adat sedikit demi sedikit tidak digunakan lagi, karena para perantau akan memilih yang lebih simpel. 


\section{Daftar Bacaan}

\section{Buku}

Amir Syarifuddin, Pelaksanaan Hukum Kewarisan Islam Dalam Lingkungan Adat Minangkabau (Gunung Agung 1984).

H. Hilman Hadikusuma, Pengantar Hukum Waris Di Indonesia (Mandar Maju 2003).

H. Zainuddin Ali, Pelaksanaan Hukum Waris Di Indonesia (Sinar Grafika 2010).

Helmy Panuh, Peranan Kerapatan Adat Nagari (Raja Grafindo Persada 2012).

Mochtar Naim Ed, Menggali Hukum Tanah Dan Hukum Waris Minangkabau, Center for Minangkabau (Studies Press 1968).

Muhammad Fu'ad Abdul Baqy, Al Mu'jam Al Mufahros Lil Al Fadhil Al Qur'an (Diponegoro 1945).

Oemar Moechthar, Perkembangan Hukum Waris Praktik Penyelesaian Sengketa Kewarisan Di Indonesia (Prenadamedia Group 2019).

Soejono Soekanto, Hukum Adat Indonesia (Rajagrafindo Persada 2012).

Soepomo, Bab-Bab Tentang Hukum Adat (Pradnya Paramita 2003).

Sri Hajati dkk, Buku Ajar Hukum Waris: Adat, Islam Dan Burgerlijk Wetboek (Airlangga University Press 2018).

Suparman Usman dan Yusuf Somawinata, Fiqh Mawaris (Gaya Media Pratama 1997).

Tsuyoshi Kato, Adat Minangkabau Dan Merantau Dalam Perspektif Sejarah (PT Balai Pustaka 2005).

\section{Laman}

Kemendikbud, 'Kedudukan Dan Peran Bundo Kanduang' (Kemendikbud, 2014) $<$ http://repositori.kemdikbud.go.id/10797/1/Kedudukan dan peran bundo kanduang.pdf $>$ accessed 16 July 2019.

\section{Makalah}

Sidi Gazalba, Konflik Penyesuaian Antara Adat. Agarna Dan Pengaruh Barat, Makalah disampaikan pada Seminar Islam di Mingkabau, Minang Permai, Padang, 1969.

HOW TO CITE: Ira Damayanti Putri, Dhea Amelisca and Sarfia Nengsih, 'Pewarisan Menurut Hukum Waris Islam Terhadap Sistem Kekerabatan Matrilineal Minangkabau' (2019) Vol. 2 No. 2 Notaire. 
--Halaman ini sengaja dibiarkan kosong-- 